\title{
Tingkat Penerapan Teknologi Pertanian dan Strategi Pengembangan Budidaya Bawang Merah (Allium cepa. L) di Desa Tes Kecamatan Bikomi Utara Kabupaten Timor Tengah Utara
}

\author{
Adrianus Seran ${ }^{\mathrm{a}}$, Werenfridus Taena ${ }^{\mathrm{b}}$ \\ ${ }^{a}$ Fakultas Pertanian, Universitas Timor, Kefamenanu, TTU - NTT, Indonesia, email: adrianusseran2019@gmail.com \\ ${ }^{b}$ Fakultas Pertanian, Universitas Timor, Kefamenanu, TTU - NTT, Indonesia, email: weren_ntt@yahoo.co.id.
}

\section{Article Info}

Article history:

Received 4 Mei 2019

Received in revised form 18 Mei 2019

Accepted 02 Juni 2019

DOI:

https://doi.org/10.32938/ag.v4i3.671

\section{Keywords:}

Teknologi

Strategi

Pengembangan

Bawang merah

\section{Abstrak}

Penelitian ini bertujuan untuk: (1) mengetahui tingkat penerapan teknologi budidaya bawang merah di Desa Tes Kecamatan Bikomi Utara Kabupaten Timor Tengah Utara, (2) menganalisis faktor internal dan eksternal serta merumuskan strategi pengembangan usahatani bawang merah di Desa Tes Kecamatan Bikomi Utara Kabupaten Timor Tengah Utara. Penelitian ini telah dilaksanakan di Desa Tes pada bulan September sampai bulan Oktober 2018 Pengumpulan data menggunakan metode survei. Penentuan sampel dilakukan secara purposive sampling dengan pertimbangan petani yang telah budidaya bawang merah selama 3 tahun di Desa Tes sebanyak 22 responden. Alat analisis yang digunakan dalam penelitian ini adalah analisis skala likert dan analisis SWOT. Hasil penelitian menyakatan bahwa teknologi pertanian yang digunakan meliputi peralatan (traktor, kultivator, motor air), dan pengelolaan usahatani bawang merah. Analisis skala likert menyakatan bahwa presentase penggunaan teknologi pada usahatani bawang merah yang sesuai anjuran adalah 76,38\% dan yang tidak sesuai anjuran adalah 23,38\%; sehingga dikategorikan sesuai anjuran. Sesuai analisis SWOT usahatani bawang merah dikelompokkan dalam kuadran I, dengan alternatif strategi antara lain: pertama strategi peningkatan modal usaha yang didukung oleh pemerintah memperoleh nilai (skor 5,78), kedua strategi akumulas modal usaha dari petani untuk mengantisipasi peningkatan harga benih (skor 5,76). Ketiga strategi pelatihan dan penyuluhan dari PPL untuk meningkatkan kualitas SDM petani ( skor 3,48).

\section{Pendahuluan}

Bawang merah (Allium cepa. L) merupakan salah satu komoditas tanaman hortikultura yang biasa diusahakan oleh petani di Indonesia. Sesuai hakekat pembangunan pertanian, pemerintah Indonesia berupaya melakukan perubahan penerapan teknologi usahatani termasuk teknologi pasca panen. Mosher (1983) mengemukakan bahwa salah satu syarat mutlak pembangunan pertanian adalah adanya teknologi usahatani yang senantiasa berubah.

Penggunaan teknologi dalam usahatani bawang merah sangat dibutuhkan oleh petani dengan harapan dapat meningkatkan produktifitas, meningkatkan efisiensi usaha. Selain itu meningkatkan nilai tambah produk yang dihasilkan serta meningkatkan pendapatan petani (Sitompul, 1995).

Teknologi yang digunakan dalam usahatani bawang merah antara lain sebagai berikut: (1) alat-alat atau mesin pertanian, (2) cara pengolahan lahan, (3) cara atau metode dalam budidaya bawang merah (Rahardi, 2008). Namun dalam kenyataannya masih banyak petani yang belum sepenuhnya menerapkan teknologi budidaya bawang merah. Hal tersebut disebabkan karena kurangnya pengetahuan petani tentang teknologi pertanian dan terbatasnya modal.

Hasil produksi bawang merah di Indonesia pada tahun 2014 sebanyak 1.233.984 ton dengan luas panen sebesar 120.704 Ha, pada tahun 2015 produks bawang merah sebesar 1.229.184 ton dengan luas panen sebesar 122.126 Ha dan pada tahun 2016 produksi bawang merah sebesar 1.446 .860 ton dengan luas panen sebesar 149.635 Ha (BPS, TTU. 2016). Pulau Jawa tetap mendominas dan kontribusinya lebih tinggi jika dibandingkan periode sebelumnya yaitu sebesar $74,89 \%$ dan luar Jawa hanya memberikan kontribusi $25,11 \%$ terhadap total luas panen bawang merah Indonesia (Kementerian Pertanian, 2015).

Provinsi Nusa Tenggara Timur (NTT) merupakan salah satu provinsi di Indonesia yang juga menghasilkan bawang merah. Produksi bawang merah $\mathrm{d}$ Provinsi Nusa Tenggara Timur berfluktuatif setiap tahun yaitu pada tahun 2014 sebanyak 2.229 ton dengan luas lahan sebesar $935 \mathrm{Ha}$, pada tahun 2015 produks bawang merah menurun menjadi 2.082 ton dengan luas lahan sebesar $1.231 \mathrm{Ha}$ dan tahun 2016 produksi bawang merah kembali meningkat menjadi 2.390 ton dengan luas lahan sebesar 1.061 Ha (BPS, TTU. 2016)

Kabupaten Timor Tengah Utara (TTU) merupakan salah satu kabupaten yang ada di Provinsi Nusa Tenggara Timur (NTT) yang memproduksi bawang merah. Produksi bawang merah di Kabupaten Timor Tengah Utara mengalam fluktuasi setiap tahun. Pada tahun 2014 produksi bawang merah sebanyak 14,8 ton dengan luas lahan sebesar 7,13 Ha dan mengalami penurunan pada tahun 2015 menjadi 9,5 ton dengan luas lahan sebesar 8 Ha dan kembali meningkat pada tahun 2016 sebanyak 56,6 ton, dan pada tahun 2017 produksi sebesar 80,5 ton dengan luas lahan sebesar 19 Ha (BPS, TTU. 2017).

Kecamatan Bikomi Utara adalah salah satu kecamatan yang ada di Kabupaten Timor Tengah Utara pada tahun 2017 berkontribusi sebesar 75 ton atau mensuplai 93\% dari total bawang merah di Kabupaten TTU, yang sebagian besar masyarakatnya bekerja sebagai petani, ber. Salah satu Desa di Kecamatan Bikomi Utara yang mengusahakan bawang merah yaitu Desa Tes dengan memanfaatkan sumberdaya air dari sungai Ekat. Usahatani bawang merah banyak diusahakan oleh para petani di Desa Tes guna memanfaatkan sumberdaya lahan, air dan untuk memperoleh pendapatan demi memenuhi kebutuhan hidup sehari-hari.

Hasil survei awal kegiatan usahatani bawang merah di Desa Tes dimula sejak tahun 2016 hingga saat ini. Pada tahun 2016 masyarakat Desa Tes memproduksi bawang merah sebanyak 2 ton dengan luas lahan sebesar 22 are dan mengalami peningkatan pada tahun 2017 yaitu sebanyak 25 ton dengan luas lahan sebesar $4 \mathrm{Ha}$, mengindikasi terjadi kenaikan produksi yang cukup signifikan.tetapi dalam produktivitas masih sangat rendah yaitu hanya berkisar 6.25 ton/Ha sedangkan produksi rata-rata nasional sudah mencapi 10,22 ton/Ha Rendahnya produktivitas disebabkan oleh kurangnya penggunan teknologi yang tepat guna dan sesuai dengan anjuran penyuluh, Joka et al. (2017) menyebutkan, adopsi teknologi petani terhadap teknologi pengelolaan masih pada level medium.

Penelitian ini bertujuan untuk: (i) mengetahui tingkat penerapan teknolog budidaya bawang merah di Desa Tes Kecamatan Bikomi Utara Kabupaten Timor Tengah Utara, (ii) menganalisis faktor-faktor internal dan eksternal serta merumuskan strategi pengembangan usahatani bawang merah di Desa Tes Kecamatan Bikomi Utara Kabupaten Timor Tengah Utara.

\section{Metode}

\subsection{Desain Penelitian}

Penelitian ini dilakukan di Desa Tes Kecamatan Bikomi Utara Kabupaten Timor Tengah Utara, pada bulan September sampai bulan Oktober 2018 Penelitian menggunakan metode survei. Data yang dikumpulkan terdiri dari data primer dan data sekunder. Data primer diperoleh melalui observasi dan wawancara langsung dengan petani berdasarkan daftar pertanyaan yang telah disiapkan. Data sekunder diperoleh dari lembaga-lembaga atau instansi-instansi yang terkait dengan penelitian ini, berupa monografi kecamatan, keadaan umum pertanian dan data-data lain yang menunjang dalam penelitian ini. Penentuan sampel dalam penelitian ini dilakukan secara purposive sampling dengan pertimbangan petani responden yang melakukan usahatani bawang merah selama 3 tahun di Desa Tes sebanyak 22 orang dijadikan responden penelitian.

\subsection{Analisis Data}

Data yang diperoleh kemudian ditabulasi dan dianalisis berdasarkan tujuan penelitian. Tujuan pertama dianalisis menggunakan analisis skala likert, sedangkan tujuan kedua dianalisis menggunakan analisis SWOT.

\section{a. Analisis Skala Likert}

Analisis skala likert dilakukan untuk memperoleh informasi tentang penerapan teknologi usahatani bawang merah di Desa Tes Kecamatan Bikomi Utara Kabupaten Timor Tengah Utara. Faktor-faktor penentu tingkat penerapan teknologi usahatani bawang merah ditampilkan Tabel 1.

Untuk mengetahui nilai interpretasi, maka terlebih dahulu mengetahui skor tertinggi $(\mathrm{X})$ dan skor terendah $(\mathrm{Y})$ untuk item penilaian dengan rumus menurut Sugiyono (2015) sebagai berikut:

$\mathrm{X}=$ Skor tertinggi likert $\mathrm{x}$ jumlah pertanyaan (angka tertinggi 10) perhatikan bobot nilai.

$\mathrm{Y}=$ Skor terendah likert $\mathrm{x}$ jumlah pertanyaan (angka terendah 5) perhatikan bobot nilai.

Selanjutnya untuk mengetahui kriteria tingkat penerapan teknologi usahatani bawang merah dihitung dengan rumus sebagai berikut:

Kategori jawaban petani responden

Sesuai anjuran $\quad=10$

Tidak sesuai anjuran $=5$

Skor tertinggi $\quad=$ jumlah pertanyaan $\mathrm{x}$ skor tertinggi

$=9 \times 10=90$

$=90 / 90 \times 100 \%$

$=100 \%$.

Skor terendah $\quad=$ jumlah pertanyaan $\mathrm{x}$ skor terendah

$=9 \times 5=45$

$=45 / 90 \times 100 \%$

$=50 \%$. 


$$
=50 \% \text {. }
$$

Ketegori $=2$ (sesuai anjuran dan tidak sesuai anjuran)

Interval $\quad=\mathrm{R} / \mathrm{K}=50 \% / 2=25 \%$

Range standar $=100 \%-25 \%=75 \%$

Berdasarkan perhitungan tersebut, dapat ditentukan kriteria pengambilan keputusan tingkat penggunaan teknologi. Kriterianya sebagai berikut, jika nilainya $\geq 75 \%$ berarti penggunaan teknologi sesuai kriterai. Sebaliknya bila nilainya $\leq 75 \%$ berarti penggunaan teknologi tidak sesuai. Lihat tabel 1

Tabel 1.Ukuran Tingkat Penerapan Teknologi Usahatani Bawang Merah D Desa Tes Kecamatan Bikomi Utara Kabupaten Timor Tengah Utara.

\begin{tabular}{cc}
\hline & Faktor Penentu Tingkat Penerapan teknologi \\
No & Usahatani bawang merah \\
\hline
\end{tabular}

1 Persiapan Benih

2 Pengolahan Lahan

3 Penanaman

4 Penyiangan

5 Pemupukan

6 Pengairan

7 Pengendalian Hama Penyakit

8 Panen

9 Pasca Panen
Bobot

$10=$ Sesuai Anjuran

5 = Tidak Sesuai Anjuran

$10=$ Sesuai Anjuran

5 = Tidak Sesuai Anjuran

$10=$ Sesuai Anjuran

5 = Tidak Sesuai Anjuran

$10=$ Sesuai Anjuran

5 = Tidak Sesuai Anjuran

$10=$ Sesuai Anjuran

5 = Tidak Sesuai Anjuran

$10=$ Sesuai Anjuran

5 = Tidak Sesuai Anjuran

$10=$ Sesuai Anjuran

5 = Tidak Sesuai Anjuran

$10=$ Sesuai Anjuran

5 = Tidak Sesuai Anjuran

$10=$ Sesuai Anjuran

5 = Tidak Sesuai Anjuran

\section{b. Analisis SWOT}

Analisis SWOT digunakan untuk membandingkan faktor eksternal dan faktor internal. Faktor eksternal terdiri dari peluang (opportunities) dan ancaman (threats) sedangkan faktor internal terdiri dari kekuatan (strengths) dan kelemahan (weaknesses). Selanjutnya menggunakan faktor internal dan eksternal untuk menentukan kuadran dan merumuskan strategi-strategi dalam menjalankan usahatani bawang merah di Desa Tes Kecamatan Bikomi Utara Kabupaten Timor Tengah Utara.

Analisis SWOT kualitatif di atas dapat dioptimalkan secara kuantitaif via perhitungan SWOT yang dioptimalkan oleh Pearce dan Robinson (1998) agar diketahui secara pasti posisi organisasi yang sebenarnya.

Perhitungan yang dilaksanakan lewat tiga tahap, yakni:

1. Tahap Pertama.

Melaksanakan perhitungan poin (a) dan muatan (b) poin unsur serta jumlah sempurna perkalian skor dan bobot $(\mathrm{c}=\mathrm{a} \times \mathrm{b})$ pada tiap-tiap unsur S-WO-T.Menghitung nilai (a) masing-masing poin unsur dijalankan secara saling bebas (penilaian terhadap sebuah poin elemen tidak boleh dipengaruhi atau mempengaruhi pengevaluasian kepada poin unsur lainnya. Opsi rentang besaran skor betul-betul memastikan akurasi pengevaluasian tapi yang biasa diterapkan ialah dari 1 sampai 10, dengan asumsi nilai 1 berarti skor yang paling rendah dan 10 berarti nilai yang paling tinggi.

Perhitungan bobot (b) masing-masing point elemen dilaksanakan secara saling ketergantungan. Artinya, penilaian kepada satu point faktor ialah dengan membandingkan tingkat kepentingannya dengan point elemen lainnya Sehingga formulasi perhitungannya ialah nilai yang telah didapatkan (jangka nilainya sama dengan banyaknya point unsur) dibagi dengan banyaknya jumlah point faktor).

2. Tahap kedua.

Melakukan pengurangan antara jumlah sempurna faktor S dengan W (d) dan faktor $\mathrm{O}$ dengan $\mathrm{T}(\mathrm{e})$; Perolehan angka $(\mathrm{d}=\mathrm{x})$ berikutnya menjadi poin atau titik pada sumbu $X$, sementara perolehan angka $(e=y)$ selanjutnya menjadi nilai atau spot pada sumbu $Y$;

3. Tahap ketiga SWOT

Mencari posisi organisasi yang dijelaskan oleh titik (x,y) pada kuadran

\section{Kuadran I (positif, positif)}

Posisi ini membuktikan sebuah organisasi yang kuat dan berpeluang. Rekomendasi taktik yang diberikan ialah Progresif, artinya organisasi dalam kondisi prima dan mantap. Sehingga benar-benar dimungkinkan untuk terus menjalankan ekspansi, memperbesar pertumbuhan dan meraih kemajuan secara maksimal

\section{Kuadran II (positif, negatif)}

Posisi ini membuktikan sebuah organisasi yang kuat tapi menghadapi tantangan yang besar. Saran taktik yang diberi yaitu Diversifikasi Strategi. Maksudnya adalah organisasi berada pada situasi mantap namun juga menghadapi sejumlah tantangan berat. Sehingga diperkirakan roda organisasi akan mengalami kesulitan untuk terus berputar jika hanya bergantung pada taktik sebelumnya. Oleh karena itu, organisasi disarankan untuk mulai memperbanyak variasi strategi taktisnya.

\section{Kuadran III (negatif, positif)}

Posisi ini menggambarkan sebuah organisasi yang lemah namun sungguhsungguh berpeluang. Anjuran taktik yang disarankan ialah Ubah Taktik, artinya organisasi disarankan untuk mengubah strategi sebelumnya. Karena, strategi yang lama dikhawatirkan susah untuk dapat menangkap kesempatan yang ada sekaligus memperbaiki performa organisasi.

\section{Kuadran IV (negatif, negatif)}

Posisi ini membuktikan sebuah organisasi yang lemah dan menghadap tantangan besar. Anjuran taktik yang diberikan adalah Strategi Bertahan artinya kondisi internal organisasi berada pada alternatif dilematis. Oleh karenanya organisasi disarankan untuk memakai strategi bertahan, mengontro performa internal supaya tak semakin terjerembab. Taktik ini dipertahankan sambil terus berusaha memperbaiki diri. Lihat tabel 2.

Table 2. perhitungan Analisa SWOT

\begin{tabular}{|c|c|c|c|c|}
\hline No, & STRENGTH & SKOR & BOBOT & TOTAL \\
\hline \multicolumn{5}{|l|}{1.} \\
\hline \multirow[t]{2}{*}{2.} & dst & & & \\
\hline & Total Kekuatan & & & \\
\hline No. & WEAKNESS & SKOR & BOBOT & TOTAL \\
\hline \multicolumn{5}{|c|}{ TEF } \\
\hline \multicolumn{5}{|l|}{2.} \\
\hline & Total Kelemahan & & & \\
\hline
\end{tabular}

\begin{tabular}{|c|c|c|c|c|}
\hline No, & OPPORTUNITY & SKOR & BOBOT & TOTAL \\
\hline \multicolumn{5}{|l|}{1.} \\
\hline 2. & dst & & & \\
\hline & Total Peluang & & & \\
\hline No. & TREATH & SKOR & BOBOT & TOTAL \\
\hline 1. & & & & \\
\hline 2. & dst & & & \\
\hline & Total Tantangan & & & \\
\hline
\end{tabular}

\section{Hasil dan Pembahasan}

\subsection{Tingkat Penerapan Teknologi Pertanian}

Usahatani bawang merah telah lama diusahakan oleh petani produsen di Desa Tes dengan penerapan teknologi yang diterapkan oleh petani sebagai berikut:

\section{Persiapan benih}

Benih merupakan salah satu kunci keberhasilan dalam suatu usahatani. Syarat benih bawang merah yang baik yaitu: umur simpan 3-4 bulan dengan umur panen 80-90 hari dan memiliki warna yang merah cerah dan tidak keropos. Seluruh petani bawang merah di Desa Tes (100\%) telah melakukan proses penyiapan benih dengan baik sesuai anjuran

2. Pengolahan lahan

Pengolahan tanah bertujuan untuk menggemburkan tanah, memperbaiki airase dan drainase serta mengendalikan gulma. Teknologi alat pertanian yang digunakan oleh petani di Desa Tes dalam proses pengolahan lahan yaitu hand traktor dan cultivator. Pengolahan tanah seharusnya dilakukan 2-3 kali dengan kedalaman $20 \mathrm{~cm}$.

Petani-petani pada lokasi penelitian sebagian besar melakukan pengolahan tanah tidak sesuai anjuran $(77,27 \%)$, karena umumnya petani responden hanya melakukan 1 kali pengolahan tanah. Sebagian kecil petani $(12,73 \%)$ melakukan pengolahan lahan sesuai anjuran yakni 2-3 kali pengolahan lahan.

3. Penanaman

Seluruh petani bawang merah di Desa Tes menggunakan bibit lokal dalam usahatani bawang merah. Jarak tanam yang dianjurkan adalah $20 \mathrm{~cm}$ x $15 \mathrm{~cm}$ Petani bawang merah di Desa Tes seluruhnya (100\%) telah melakukan penanaman sesuai anjuran. Kendalanya teknologi yang digunakan dalam hal proses penanaman masih secara tradisional yakni menggunakan tugal (kayu yang diruncingkan)

4. Pemeliharaan

a) Penyiangan

Penyiangan pada dasarnya dilakukan pada saat tanaman bawang merah berumur 21 hari setelah tanam (HST). Hasil penelitian menunjukkan 54,55\% sesuai anjuran, sedangkan $44,45 \%$ tidak sesuai anjuran.

b) Pemupukan;

Pemupukan pada umumnya dilakukan sebanyak 3 kali yaitu pemupukan dasar dan pemupukan susulan. Hasil penelitian menunjukan bahwa 54,55\% petani belum melakukan pemupukan sesuai anjuran terutama berkaitan dengan pupuk yang digunakan dan waktu pemupukan, sedangkan 44,45\% telah melakukan pemupukan dan menggunakan pupuk sesuai anjuran. Pupuk yang digunakan oleh petani di Desa Tes yaitu pupuk bokasi padat, pupuk hayati dan pupuk Plant Growth Promoting Rhizobacteria (PGPR). 


\section{c) Pengairan;}

Petani bawang merah di Desa Tes umumnya $(90,91 \%)$ telah melakukan pengairan sesuai anjuran yakni saat umur tanaman berumur 1-7 hari dilakukan penyiraman secara rutin. Dilanjutkan dengan melakukan penyiraman 1 atau 2 kali dalam seminggu. Penyiraman atau pengairan dilakukan menggunakan teknologi mesin sedot air (motor air). Sebagian kecil $(9,09 \%)$ petani tidak melakukan penyiraman sesuai anjuran karena motivasi kerja yang kurang.

d) Pengendalian hama penyakit;

Hasil penelitian menunjukkan bahwa pengendalian penyakit pada tanaman bawang merah $44,45 \%$ petani telah melakukan sesuai anjuran. Dimana untuk pengendalian penyakit para petani menggunakan pestisida nabati, sedangkan untuk pengendalian hama para petani menggunakan pestisida anorganik.

5. Panen dan Pasca panen;

Hasil penelitian menyatakan bahwa seluruh petani bawang merah di Desa Tes $(100 \%)$ telah melakukan pemanenan sesuai waktu panen yakni pada saat tanaman berumur 80-90 hari. Demikian pula proses penangan hasil pasca panen petani telah dilakukan sesuai anjuran (100\%), dimana petani melakukan pengeringan salama \pm 1 minggu dengan cara disebarkan bawang di permukaan tanah dengan tupukan tipis dan selanjutnya menyediakan rumah atau pondok kecil yang didalamnya tersedia para-para untuk tempat penyimpanan tabel 3 .

Tabel 3. Analisis Tingkat Penerapan Teknologi Usahatani Bawang Merah Di Desa Tes Kecamatan Bikomi Utara Kabupaten Timor Tengah Utara.

\begin{tabular}{|c|c|c|c|c|c|}
\hline $\begin{array}{l}\text { Faktor-Fakor } \\
\text { Penentu }\end{array}$ & $\begin{array}{c}\text { Sesuai } \\
\text { Anjuran }(\mathrm{X})\end{array}$ & $\begin{array}{l}\text { Tidak Sesuai } \\
\text { Anjuran }(Y)\end{array}$ & $\begin{array}{l}\text { Poin (10 } \\
\text { x X }\end{array}$ & $\begin{array}{l}\text { Poin (5) } \\
\text { X Y }\end{array}$ & $\sum$ \\
\hline 1 Persiapan benih & 22 & 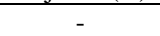 & 220 & 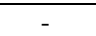 & 220 \\
\hline 2 Pengolahan lahan & 5 & 17 & 50 & 85 & 135 \\
\hline 3 Penanaman & 22 & - & 220 & - & 220 \\
\hline 4 Penyiangan & 12 & 10 & 120 & 50 & 170 \\
\hline 5 Pemupukan & 10 & 12 & 100 & 60 & 160 \\
\hline 6 Pengairan & 22 & - & 220 & - & 220 \\
\hline $\begin{array}{l}7 \text { Pengendalian hama } \\
\text { penyakit }\end{array}$ & 10 & 12 & 100 & 60 & 160 \\
\hline 8 Panen & 22 & - & 220 & - & 220 \\
\hline 9 Pasca panen & 22 & - & 220 & - & 220 \\
\hline Total & & & 1.470 & 255 & 1.725 \\
\hline
\end{tabular}

Sumber: Olahan Data Primer 2019

Penilaian interpretasi responden terhadap tingkat penerapan teknologi usahatani bawang merah dilakukan dengan menggunakan rumus index $\%$. Tahapan analisisnya sebagai berikut:

Keterangan:

$$
\begin{aligned}
\mathrm{X} & =\text { Total skor } / \mathrm{X} \text { x } 100 \\
& =1.470 / 220 \times 100 \\
& =\mathbf{6 6 8 , 1 8} \\
& =\text { Total skor } / \mathrm{Y} \text { × } 100 \\
& =255 / 110 \times 100 \\
\mathrm{Y} & =\mathbf{2 0 4 , 5 4} \\
\mathrm{X}+\mathrm{Y} & =668,18+204,54 \\
& =\mathbf{8 7 2 , 7 2}
\end{aligned}
$$

Berdasarkan hasil tersebut, diketahui bahwa skor tertinggi sebesar 668,18 dan skor terendah sebesar 204,54 dengan total skor penggunaan teknologi skor tertinggi dan terendah sebesar 872,72. Presentase penggunaan teknologi pada usahatani bawang merah yang sesuai anjuran adalah $76,38 \%$ dan yang tidak sesuai anjuran adalah 23,38\%. Oleh kerena itu dapat disimpulkan bahwa penggunaan teknologi budidaya bawang merah di Desa Tes dikategorikan sesuai anjuran (dibandingkan dengan kriteria penentuan yakni $\geq 75 \%$ dikategorikan sesuai anjuran), sesuai dengan penelitian Joka et al. (2017) terkait adopsi teknologi pada usahatani padi sawah di Kabupaten Kupang .

\subsection{Identifikasi Faktor Internal Dan Eksternal Serta Strategi Pengembangan}

\section{a. Identifikasi Faktor Internal dan Eksternal}

Faktor internal yang mendukung usahatani bawang merah adalah adanya motivasi yang kuat dari petani (sumberdaya manusia yang baik) dan kualitas produk yang baik. Faktor internal yang menghambat diantaranya pendidikan petani, jaringan pemasaran dan modal usaha yang terbatas.

Faktor eksternal yang menjadi ancaman adalah banjir dan/atau kekeringan pada sempadan sungai Ekat (Noel Ekat). Sungai ini merupakan sungai yang melintasi dua negara yakni Indonesia dan Timor Leste, sehingga aktifitas pada wilayah lain dapat menyebabkan banjir pada wilayah lain. Pertanian tidak konservatif dalam jangka panjang dapat menyebabkan kekeringan. Taena, W et al (2018) menyatakan aktifitas pertanian yang tidak konservatif pada sempadan sungai Ekat dapat menyebabkan dampak negatif bagi petani pada wilayah lainnya di wilayah perbatasan negara. Sebelumnya Taena W et al (2016) menyatakan aktifitas pertanian pada bagian hulu sungai dapat mempengaruhi aktifitas pertanian pada bagian tengah dan hilir sungai. Selain ancaman, adanya dukungan pemerintah dan kerjasama dengan swasta merupakan peluang dari usahatani bawang merah ini. Lihat tabel 4.

\section{b. Strategi Pengembangan Usahatani Bawang Merah Desa Tes}

Setelah identifikasi faktor internal dan eksternal dilakukan skoring untuk mengetahui posisi skala pengembangan usahatani bawang merah di Desa Tes dalam kuadran SWOT. Hasil analisis menunjukan bahwa titik koordinatnya

\begin{tabular}{|c|c|}
\hline Peluang & Ancaman \\
\hline $\begin{array}{l}\text { a. Adanya pelatihan dan penyuluhan } \\
\text { dari PPL } \\
\text { b. Tersedia benih bermutu } \\
\text { c. Adanya dukungan dari pemerintah } \\
\text { dan kemitraan dengan swasta } \\
\text { d. Jenis tanah yang mendukung }\end{array}$ & $\begin{array}{ll}\text { a. } & \text { Serangan hama penyakit } \\
\text { b. Harga benih } \\
\text { c. Adanya bawang impor dari } \\
\text { d. luar } \\
\text { danjir dan/atau kekeringan }\end{array}$ \\
\hline
\end{tabular}
adalah 0,37 : 1,06 berada pada kuadran I (Gambar 1) yang artinya pengembangan usahatani bawang merah di Desa Tes memiliki peluang dan kekuatan yang sanga baik. Strategi yang dapat diterapkan adalah strategi agresif, yang berarti petani produsen dapat memanfaatkan peluang dan kekuatan yang ada untuk mengatasi ancaman dan kelemahan.

\section{Tabel 4. Identifikasi Faktor Internal Dan Eksternal}

\begin{tabular}{lll}
\hline \multicolumn{1}{c}{ Kekuatan } & \multicolumn{1}{c}{ Kelemahan } \\
\hline a. & Kualitas sumber daya manusia & a. Pendidikan petani \\
b. Teknologi pertanian & b. Informasi pasar \\
c. Metode penyimpanan & c. Distribusi pasar \\
d. Penggunaan pupuk & d. Modal usaha \\
e. & Kualitas produk & \\
\hline
\end{tabular}

Selanjutnya dirumuskan strategi-strategi pada masing-masing kuadran. Rumusan strategi tersebut dilanjutkan dengan analisis matriks QSPM yang bertujuan untuk menetapkan kemenarikan relatif (relative attractiveness) dari strategi-strategi yang bervariasi yang telah dipilih dan untuk menentukan strategi yang dianggap paling baik untuk diimplementasikan.

Berdasarkan hasil yang diperoleh pada hasil analisis QSPM, dapat diurutkan skor nilai tertinggi sampai yang terendah. Strategi yang memiliki nilai tertinggi sebesar 5,78 yakni peningkatan modal usaha yang didukung oleh pemerintah. Strategi berikutnya adalah pemupukan modal untuk antisipasi peningkatan harga bibit (skor 5,76), dan strategi dengan nilai skor terendah (sebesar 3,48) yakni memanfaatkan adanya pelatihan dan penyuluhan untuk meningkatkan kualitas SDM petani.

Analisis SWOT merupakan suatu analisis yang digunakan untuk membandingkan faktor internal dan eksternal yang terdiri dari kekuatan, kelemahan, peluang dan ancaman. Berdasarkan skor pembobotan dari faktor internal dan eksternal pada tabel IFAS dan EFAS diatas akan digunakan untuk mencari titik koordinat dalam grafik analisis SWOT. Rumus yang digunakan untuk mencari titik koordinat tersebut adalah: skor $\mathbf{S}$ dikurang skor $\mathbf{W}$ dan skor O dikurang skor $\mathbf{T}$ sehingga titik koordinat pada grafik SWOT adalah: 1,44 $0,52: 1,72-0,79=0,93: 0,92$. Untuk lebih jelas dapat dilihat pada gambar 3 .

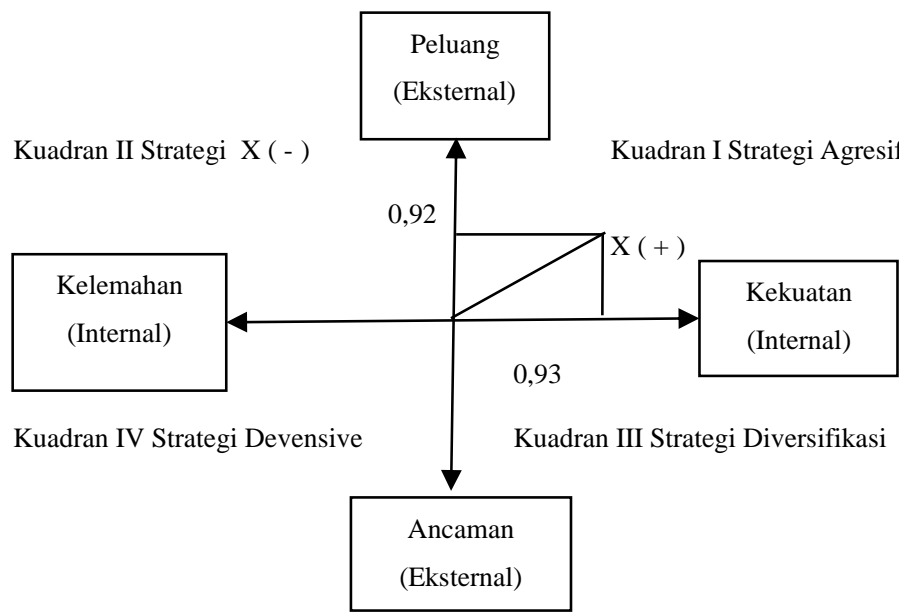

Gambar 1: Grafik Analisis SWOT.

\section{Kuadran I (positif, positif)}

Posisi skala pengembangan usahatani bawang merah di Desa Tes dalam kuadran SWOT pada gambar 1 menunjukan bahwa titik koordinat yaitu 0,93: 0,92 berada pada kuadran I yang artinya pengembangan usahatani bawang merah di Desa Tes memiliki peluang dan kekuatan yang sangat baik. Petani produsen dapat memanfaatkan peluang dan kekuatan yang ada untuk mengatasi ancaman dan kelemahan yang ada.

\section{Kuadran II (positif, negatif)}

Posisi ini menunjukan bahwa pengembangan usahatani bawang merah sangat kuat, tetapi menghadapi tantangan yang sangat besar. Rekomendasi strategi yang diberikan adalah diversifikasi strategi, artinya usaha pengembangan bawang merah di Desa Tes berada dalam kondisi baik namun menghadapi 
tantangan berat. Oleh karena itu diharapkan pengembangan usahatani bawang merah agar segerah memperbanyak strategi.

\section{Kuadran III (negatif, positif)}

Posisi ini pertanda bahwa pengembangan usahatani bawang merah sedang lemah namun memiliki peluang. Rekomendasi yang diberikan adalah ubah strategi, artinya usahatani bawang merah diharapkan agar mengubah strategi sebelumnya, dikarenakan strategi sebelumnya sulit untuk menangkap peluang yang ada.

\section{Kuadran IV (negatif, negatif)}

Posisi ini menunjukan bahwa usahatani bawang merah berada dalam kondisi lemah dan menghadapi tantangan besar. Rekomendasi strategi yang diberikan adalah strategi bertahan, artinya kondisi usahatani bawang merah berada dalam pilihan dilema. Oleh karena itu usahatani bawang merah disarankan agar menggunakan strategi bertahan.

\subsection{Rumusan Strategi Pengembangan}

Berdasarkan faktor-faktor internal dan eksternal pada tabel 5 dapat dirumuskan strategi pengembangan usahatani bawang merah di Desa Tes. Rincian strategi ditampilkan pada Tabel 5.

\section{Tabel 5. Matrix SWOT}

\begin{tabular}{|c|c|c|}
\hline IFAS & $\begin{array}{ll} & \text { STRENGTHS (S) } \\
\text { 1. } & \text { Pengalaman petani } \\
\text { 2. } & \text { Teknologi Pertanian } \\
\text { 3. Jenis tanah yang } \\
& \text { mendukung } \\
\text { 4. } & \text { Penggunaan Pupuk } \\
\text { 5. } & \text { Kualitas Produk } \\
\end{array}$ & \begin{tabular}{ll}
\multicolumn{2}{c}{ WEAKNESSES $(\mathbf{W})$} \\
1. & Pendidikan petani \\
2. & Informasi pasar \\
3. & Distribusi pasar \\
4. & Modal usaha
\end{tabular} \\
\hline 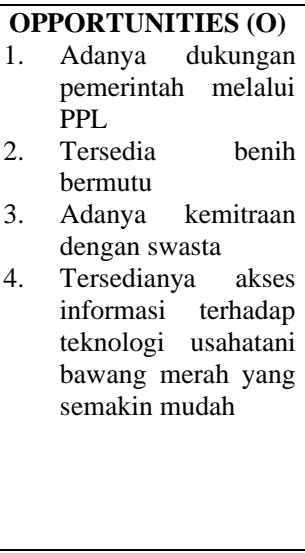 & $\begin{array}{l}\text { STRATEGI S-O } \\
\text { Pelaksanaan } \\
\text { pelatihan bagi } \\
\text { petani bawang } \\
\text { merah untuk } \\
\text { meningkatkan } \\
\text { keterampilan } \\
\text { Meningkatkan } \\
\text { kualitas produk } \\
\text { melalui penyediaan } \\
\text { benih bermutu dan } \\
\text { penanganan pasca } \\
\text { panen yang tepat } \\
\text { Penggunaan } \\
\text { informasi untuk } \\
\text { memudahkan } \\
\text { pemasaran }\end{array}$ & \begin{tabular}{ll} 
& \multicolumn{2}{c}{ STRATEGI W-O } \\
1. & $\begin{array}{l}\text { Meningkatkan } \\
\text { pendidikan petani } \\
\text { dengan } \\
\text { mengadakan }\end{array}$ \\
& pelatihan dan \\
penyuluhan. & \\
2. & $\begin{array}{l}\text { Perluasan dan } \\
\text { kerjasama dengan }\end{array}$ \\
& koperasi dan swasta
\end{tabular} \\
\hline TREATS (T) & STR & STRA \\
\hline $\begin{array}{l}\text { 1. Serangan hama } \\
\text { penyakit } \\
\text { 2. Harga benih } \\
\text { 3. Adanya bawang } \\
\text { impor dari luar } \\
\text { 4. Banjir dan/atau } \\
\text { kekeringan }\end{array}$ & $\begin{array}{ll}\text { 1. } & \text { Menyediakan } \\
\text { teknologi } \\
\text { pengendalian } \\
\text { hama secara } \\
\text { terpadu untuk } \\
\text { mengatasi } \\
\text { serangan hama } \\
\text { penyakit } \\
\text { 2. } \\
\text { Meningkatkan } \\
\text { kualitas produk } \\
\text { untuk mampu } \\
\text { bersaing dengan } \\
\text { bawang impor. }\end{array}$ & $\begin{array}{ll}\text { 1. } & \text { Meningkatkan } \\
\text { keterampilan petani } \\
\text { untuk mengatasi } \\
\text { hama penyakit } \\
\text { 2. } & \text { Meningkatkan } \\
\text { pendidikan petani } \\
\text { sehingga produksi } \\
\text { dan produktifitas } \\
\text { bawang merah } \\
\text { dengan kualitas } \\
\text { tinggi }\end{array}$ \\
\hline
\end{tabular}

\subsection{Analisis Quantitative Strategic Planning Matriks (QSPM)}

Analisis matriks QSPM bertujuan untuk menetapkan kemenarikan relatif (relative attractiveness) dari strategi-strategi yang bervariasi yang telah dipilih dan untuk menentukan strategi yang dianggap paling baik untuk diimplementasikan. Matriks SWOT menghasilkan strategi-strategi alternatif yaitu strategi pemanfaatan pelatihan dan penyuluhan dari PPL unutk meningkatkan kualitas SDM petani, strategi peningkatan modal usaha yang didukung dengan adanya dukungan dari pemerintah dan peningkatan modal usaha untuk mengantisipai harga benih. Kemudian strategi-startegi alternatif tersebut, disusun dalam matriks QSPM dan pemilihan strategi didasarkan atas pandangan peneliti. Faktor yang memiliki daya tarik dari masing-masing faktor eksternal dan faktor internal di beri nilai 1 (tidak menarik) sampai dengan nilai 4 (sangat menarik). Lebih lanjut hasil analisis (QSPM) dapat di lihat pada Tabel 6.

Berdasarkan hasil yang diperoleh pada tabel 6 di atas, maka dapat diurutkan skor nilai TAS tertinggi sampai yang terendah sebagai berikut: Strategi I memiliki nilai TAS tertinggi sebesar 6,41, diikuti strategi III dengan nilai TAS sebesar 6,1 dan strategi II dengan nilai TAS sebesar 5,88. Dari perengkingan alternatif strategi tersebut maka dapat disusun alternatif strategi pengembangan usahatani bawang merah yaitu pertama strategi pelaksanaan pelatihan bagi petani bawang merah untuk meningkatkan keterampilan, kedua strategi meningkatkan kualitas produk melalui penyediaan benih bermutu dan penanganan pasca panen yang tepat, dan ketiga strategi penggunaan informasi untuk memudahkan pemasaran.

Tabel 6.Analisis QSPM Usahatani Bawang Merah Di Desa Tes Kecamata Bikomi Utara Kabupaten Timor Tengah Utara.

\begin{tabular}{ccccc}
\hline Faktor-Faktor & Kode Bobot & Strategi & Strategi Strategi \\
\cline { 3 - 4 } & & I & II & III \\
\hline
\end{tabular}

\section{Kekuatan:} AS TAS AS TAS AS TAS

\begin{tabular}{|c|c|c|c|c|c|c|c|}
\hline pengalaman petani & $\mathrm{S} 1$ & 0,12 & 3 & 0,36 & 3 & 0,36 & 30,36 \\
\hline Teknologi pertanian & $\mathrm{S} 2$ & 0,14 & 4 & 0,56 & 3 & 0,42 & 30,42 \\
\hline Jenis tanah yang mendukung & S3 & 0,09 & 3 & 0,27 & 2 & 0,18 & 30,27 \\
\hline Penggunaan pupuk & S4 & 0,12 & 3 & 0,36 & 3 & 0,36 & 30,36 \\
\hline Kualitas produk & S5 & 0,13 & 4 & 0,52 & 4 & 0,52 & 40,52 \\
\hline \multicolumn{8}{|l|}{ Kelemahan : } \\
\hline Pendidikan petani & W1 & 0,12 & 3 & 0,36 & 3 & 0,36 & 20,36 \\
\hline Informasi pasar & $\mathrm{W} 2$ & 0,09 & 3 & 0,27 & 2 & 0,18 & 20,18 \\
\hline Distribusi pasar & W3 & 0,07 & 2 & 0,14 & 2 & 0,14 & 20,14 \\
\hline Modal usaha & W4 & 0,12 & 4 & 0,48 & 3 & 0,36 & 30,3 \\
\hline \multicolumn{8}{|l|}{ Peluang : } \\
\hline $\begin{array}{l}\text { Adanya dukungan pemerintah } \\
\text { melalui PPL }\end{array}$ & $\mathrm{O} 1$ & 0,16 & 4 & 0,64 & 3 & 0,48 & 40 \\
\hline Tersedia beni bermutu & $\mathrm{O} 2$ & 0,13 & 3 & 0,39 & 4 & 0,52 & 30,39 \\
\hline $\begin{array}{l}\text { Adanya kemitraan dengan } \\
\text { swasta }\end{array}$ & $\mathrm{O} 3$ & 0,14 & 4 & 0,56 & 4 & 0,56 & 30,42 \\
\hline Tersedianya akses informasi & $\mathrm{O} 4$ & 0,18 & 4 & 0,72 & 3 & 0,54 & 40,72 \\
\hline \multicolumn{8}{|l|}{ Ancaman : } \\
\hline Serangan hama penyakit & $\mathrm{T} 1$ & 0,09 & 2 & 0,18 & 2 & 0,18 & 20,1 \\
\hline Harga beni & $\mathrm{T} 2$ & 0,12 & 2 & 0,24 & 3 & 0,36 & 20,24 \\
\hline $\begin{array}{l}\text { Adanya bawang impor dari } \\
\text { luar }\end{array}$ & $\mathrm{T} 3$ & 0,10 & 2 & 0,2 & 2 & 0,2 & 30, \\
\hline Banjir dan/atau kekeringan & $\mathrm{T} 4$ & 0,08 & 2 & 0,16 & 2 & 0,16 & 30,2 \\
\hline Total: & & & & 6,41 & & 5,88 & 6,1 \\
\hline \multicolumn{8}{|c|}{ Sumber: Analisis Data Primer 2018} \\
\hline \multicolumn{8}{|l|}{ AS $\quad$ :Attraktivenass Score } \\
\hline \multicolumn{8}{|c|}{ TAS : Total Attraktivenass Score } \\
\hline
\end{tabular}

\section{Simpulan}

Berdasarkan hasil penelitian yang dilakukan di Desa Tes Kecamatan Bikomi Utara Kabupaten Timor Tengah Utara maka dapat disimpulkan bahwa:

Presentase penggunaan teknologi pada usahatani bawang merah yang sesuai anjuran adalah $76,38 \%$ dan yang tidak sesuai anjuran adalah $23,38 \%$. Oleh kerena itu dapat disimpulkan bahwa tingkat penggunaan teknologi budidaya bawang merah di Desa Tes dikategorikan baik atau sesuai anjuran.

Analisis situasi menunjukkan usahatani bawang merah berada dalam kuadran I yang berarti dapat menggunakan kekuatan sehingga dapat memanfaatkan peluang yang ada atau berada pada strategi progresif. Strategistrategi yang direkomendasikan sesuai dengan analisis QSPM adalah pertama strategi pelaksanaan pelatihan bagi petani bawang merah untuk meningkatkan keterampilan (skor 6,41), kedua strategi meningkatkan kualitas produk melalui penyediaan benih bermutu dan penanganan pasca panen yang tepat (skor 6,1), dan ketiga strategi penggunaan informasi untuk memudahkan pemasaran (skor 5,88 ). Peningkatan keaktifan dalam berkelompok, dan tradisi gotong royang serta mengurangi tradisi tebas bakar pada lahan pertanian.

\section{Pustaka}

BPS. 2016. Kabupaten Timor Tengah Utara. Statistik Indonesia, 2016.

BPS. 2017. Kabupaten Timor Tengah Utara Dalam Angka, 2017.

Kementerian Pertanian. 2015. Outlook Komoditas Pertanian Pertanian Subsektor Hortikltura Bawang Merah. Pusat Data dan Sistem Informasi Pertanian. Jakarta.

Joka U, Anggraeni L, Fariyanti A. 2017. Dampak Program Pengembangan Usaha Agribisnis Pedesaan (PUAP) Terhadap Adopsi Teknologi Petani Padi di Kabupaten Kupang Provinsi NTT. Prosiding Seminar Nasional Pertanian IV, Kupang, Vol 4. Kupang: UNDANA. Pp. 445-455.

Nurmalinda dan Suwardi. 1995. Potensi Wilayah Pengembangan Bawang Merah. Pusat Penelitian Dan Pengembangan Horttikultura. Badan Penelitian Dan Pengembangan Pertanian. Jakarta.

Mosher. 1983. Menggerakan Dan Membangun Pertanian. Yasaguna. Jakarta.

Pearce dan Robinson.1998. Manajemen Strategis (Formulasi, Implementasi, dan Pengendalian). Salemba Empat. Yogyakarta.

Rangkuti. 2008. Analisis SWOT Teknik Membedah Kasus Bisnis. PT. Gramedia Pustaka Utama. Jakarta.

Sitompul. 1995. Analisis Pertumbuhan Tanaman. Gadjah Mada University Press. Yogyakarta.

Soekartawi. 1996. Pembangunan Pertanian. Penerbit Raja Grafindo Persada, Jakarta.

Sugiyono. 2015. Metode Penelitian Kombinasi (Mix Methods). Bandung: Alfabeta 
Taena W, Kolopaking LM, Juanda B, Barus B, Boer R. 2018. An Institutional Model of Transboundary Watershed Management Toward Sustainable Development. Jurnal Manajemen Hutan Tropika 22 (1): 35-46.

Taena W, Kolopaking LM, Barus B, Boer R, Juanda B. 2018. The Implication of Spatial Ecology Dependence on Spatial Arrangement in Boundary Area. Jurnal Manajemen Hutan Tropika 24 (1): 7-15.

Yudhoyono. 2006. Pengembangan Pertanian Indonesia Dari Revolusi Hijau Ke Pertanian Berkelanjutan 